\title{
Uso de imagens nos artigos científicos: visualizar, reter, divulgar, aprender
}

\author{
The use of images in scientific articles: visualizing, memorizing, \\ disseminating, learning
}

\section{El uso de imágenes en artículos científicos: visualizar, retener, divulgar, aprender}

Christovam Barcellos |christovam.barcellos@icict.fiocruz.br

Editor científico da Reciis

Fundação Oswaldo Cruz, Instituto de Comunicação e Informação Científica e Tecnológica em Saúde (Icict), Laboratório de Informação em Saúde. Rio de Janeiro, RJ, Brasil.

Alguns segundos são, em geral, dedicados por usuários da internet para identificar interesses, seguir ou abandonar uma determinada página. Várias estratégias têm sido desenvolvidas para reter a atenção de usuários e leitores assim que as páginas se abrem na tela. Fotografias, banners chamativos, títulos fortes, vídeos e gráficos são exemplos de recursos usados, e por vezes exagerados, por autores e editores para despertar o interesse de leitura de textos ou para criar imagens sintéticas sobre resultados e esquemas de análise ${ }^{1}$. Uma das iniciativas que merece ser destacada é protagonizada pelo grupo Information is beautiful [www.informationisbeautiful.net/tag/health], que traz ideias para transformar a informação, não necessariamente quantitativa, em infográficos e diagramas.

No campo dos artigos científicos, algumas revistas, como as publicadas pela Plos [http://www.plos.org/], têm colado imagens ao lado das chamadas dos artigos para chamar a atenção dos leitores. Várias revistas eletrônicas têm aceitado vídeos, sons e imagens, além de gráficos coloridos produzidos pelos autores de artigos. Este material, considerado suplementar, pode ser destacado do texto do artigo e exposto na página principal da revista, ou em seções de documentos multimídia. Com o avanço das Tecnologias de Informação e Comunicação (TIC), uma grande diversidade de plataformas tem sido usada para a disponibilização desse rico material. Por exemplo, dados tabulares usados em artigos podem ser exibidos em gráficos dinâmicos e interativos usando a plataforma Tableau [www.tableau.com/solutions/capabilities]. Alguns desses materiais são divulgados em mídias sociais, como twitter e facebook, como forma de atrair possíveis leitores para as revistas ou um determinado artigo.

Uma vez conquistado o leitor, este poderá navegar e interagir em outros espaços da web, para fora dos domínios da editora, atraído por referências dos artigos, links para páginas e plataformas de dados. Os próprios serviços de busca bibliográfica, como o Pubmed [www.ncbi.nlm.nih.gov/pubmed] oferecem agora gráficos com estatísticas sobre publicações, figuras retiradas de artigos, além da lista de artigos demandada.

Muito se tem debatido sobre os efeitos negativos e positivos dessas práticas no processo de apreensão e aprendizado de conteúdos. O uso repetido e indiscriminado de imagens e esquemas, descolados de textos 
explicativos ao mesmo tempo em que mobiliza leitores, disputa atenções, não permitindo a reflexão e aprendizado por parte do leitor ${ }^{2}$. Ao mesmo tempo, recursos gráficos digitais têm sido crescentemente utilizados como tecnologia de educação e forma de envolvimento de alunos ${ }^{3}$.

Para os pesquisadores, esses novos padrões de disponibilização de esquemas metodológicos e resultados representam um grande desafio de síntese. Além disso, há sempre o risco desse material "suplementar" se descolar do contexto em quem foi produzido, gerando interpretações equivocadas ou simplificações.

É inegável que uma imagem pode ajudar a transmitir uma ideia ou resumir resultados. Afinal, estas têm sido tradicionalmente as funções de gráficos, fotografias, quadros e mapas, amplamente aceitos no mundo acadêmico. A diferença que se impõe, neste caso, é a maior liberdade que os autores têm de utilizar recursos multimídia e imagens para demonstrar uma determinada ideia ou resultado ${ }^{7}$. As imagens produzidas ou reproduzidas nos artigos podem ser empregadas para fins didáticos, em aulas, seminários e documentos. As revistas Plos, por exemplo, permitem que as imagens de artigos sejam salvas em formato ppt, o que facilita seu uso em aulas por outros leitores e autores. Obviamente, todos os cuidados devem ser tomados para se citar os autores do artigo e da imagem, e permitir a recuperação do contexto em que esta imagem foi gerada.

O Portal de Periódicos da Fiocruz [http://www.periodicos.fiocruz.br/] recém-lançado traz uma importante contribuição neste sentido. O portal reúne as produções de sete revistas científicas sediadas na Fiocruz, permitindo a recuperação simultânea de artigos nelas publicados usando palavras-chave, autores ou datas. Além disso, o portal prevê a disponibilização de infográficos gerados pelos autores e vídeos sobre temas atuais, que também podem ser buscados por meio de metadados.

Um bom exemplo do uso de imagens é trazido pelo artigo de Juliana Gonçalves Reis e colaboradores (Aplicabilidade do binômio indexação e recuperação da informação para editores e autores), que mostra como se pode potencializar a recuperação de informações por meio da relação entre metadados de produções científicas. As figuras produzidas ajudam a fixar conceitos aludidos no texto e propor um modelo para sua operacionalização. Não por acaso, este artigo inaugura a seção de Imagens Comentadas da Reciis que tem como objetivo promover o debate sobre o uso de imagens, fotografias, gravuras, desenhos ou infográficos na comunicação, informação e saúde.

Neste e em diversos outros casos é importante lembrar que as ferramentas existentes na internet avançaram tremendamente em estratégicas de busca de textos, incorporando por exemplo a similaridade fonética para ampliar possibilidades de encontrar um determinado termo ou expressão. No entanto, a recuperação de imagens baseada em conteúdo ainda é rudimentar e depende de um conjunto de metadados que devem ser acoplados a essas imagens no momento da sua divulgação4.

Também relacionado a esses desafios, esta edição traz o interessante ensaio "O método lógico para redação científica”, de Gilson Luiz Volpato, em que se retoma o processo de produção de artigos não apenas do aspecto de sua coerência interna, mas principalmente como produto de comunicação com diversos públicos.

Na seção de Notas de conjuntura, o artigo de Marcos Dantas traz uma importante reflexão sobre os desafios para o novo governo (federal) na área de comunicação, que estão nitidamente ligados ao processo de democratização dos meios de comunicação de massa e um novo papel das mídias sociais. O artigo de Jhessica Reia e Pedro Nicoletti Mizukami aborda as perspectivas de aperfeiçoamento da lei de direitos autorais por esse novo governo.

Entre os artigos originais publicados nesta edição, o texto de Gills Vilar Lopes e Fabiola Faro Eloy Dunda mostra que a recente epidemia de Ebola na África impõe uma nova governabilidade global para o seu enfrentamento e a necessidade de análises conjuntas e cooperações internacionais. Ana Paula Bernardo Mendonça e André Pereira Neto propõem critérios e instrumentos para avaliação da qualidade da informação em sites de saúde, tomando como exemplo outras iniciativas de avaliação existentes no mundo. O artigo "Comunicação e saúde na enfermagem: um estudo bibliométrico", de Yolanda Coppen Martin e Arquimedes Pessoni, avalia a produção científica de grupos de pesquisa de enfermagem sobre o tema da 
comunicação e informação, demonstrando lacunas e potencialidades deste tema para esses profissionais. Felipe Dutra Asensi e colaboradores discutem as tendências crescentes de judicialização da saúde que têm priorizado os interesses de indivíduos em detrimento de ações coletivas de vacinação. Mônica de Caldas Rosa dos Anjos e colaboradores demonstram, por meio de ferramentas de análise de redes, a possibilidade de reconhecer ligações entre atores sociais envolvidos na produção e disseminação do conhecimento, como professores, estudantes e comunidades. No relato de experiência, Lucas Veras de Andrade e Joimara Lima Santos analisam as situações de estresse entre profissionais que atuam nas bibliotecas da Universidade Estadual do Piauí.

A seção de resenhas traz o artigo "Os desafios para uma nação conectada - indo além da introdução" de Veridiana Alimonti sobre o livro Caminhos para a universalização da internet banda larga: experiências internacionais e desafios brasileiros. Já o artigo de Ariélly Cristina Fidelis e colaboradores analisa o sofrimento e dilemas pessoais retratados no filme "Mil Vezes Boa Noite" de Erik Poppe.

Neste volume passaremos a adotar a numeração da página individualmente para cada artigo. A Reciis é uma revista eletrônica e caminha para reforçar esse conceito. Esta abordagem é utilizada por periódicos como os da Plos [http://www.plos.org/].

Boa leitura e boas imagens a todos.

\section{Referências}

1. Elsevier (2015) Content Innovation: Give your research the impact it deserves. Acessado em março de 2015. www.elsevier.com/about/content-innovation.

2. Raymond JE; O'Brien JL (2009) Selective Visual Attention and Motivation: The Consequences of Value Learning in an Attentional Blink Task. Psychological Science. 20: 981-988, doi:10.1111/j.14679280.2009.02391.x

3. Sadik A. (2008) Digital storytelling: a meaningful technology-integrated approach for engaged student learning. Educational Technology Research and Development. 56(4): 487-506.

4. Souza RR (2006) Sistemas de recuperação de informações e mecanismos de busca na web: panorama atual e tendências. Perspectivas em Ciência da Informação. 11 (2): 161-173. 
RECIIS 2015, jan-mar; 9(1): | www.reciis.icict.fiocruz.br | e-ISSN 1981-6278 